\title{
The Cost-Of-Living In Northwest Missouri
}

Jason T. White, (jwhite@mail.nwmissouri.edu), Northwest Missouri State University

\begin{abstract}
The cost-of-living in Maryville is approximately $90.3 \%$ of the national average of 324 cities nationwide. Eight Missouri cities participated in the official study under the rules of the American Chamber of Commerce Research Association (ACCRA). Separate from this study, but applying identical standards of calculation during the same time period, we conducted a cost-of-living study for Maryville, Bethany and Trenton, Missouri. Bethany's cost-of-living came in at $94.9 \%$ of the national average, while Trenton's was slightly higher, but still well below the national average, at 95.7\%. Incorporating these three city's data into the Missouri Average as calculated by ACCRA yielded a $1.1 \%$ increase, making the cost-of-living for the state of Missouri 93.7\%. This resulted in a seventeenth place finish for Missouri when ranked against all other state composite indices. Without our data included, the Missouri Department of Economic Development reported that during the $3^{\text {rd }}$ quarter, 2002 the state had the thirteenth-lowest cost-of-living in the United States.
\end{abstract}

\section{INTRODUCTION}

$T$

he cost-of-living in Maryville is approximately $90.3 \%$ of the national average of 324 cities nationwide. Eight Missouri cities participated in the official study under the rules of the American Chamber of Commerce Research Association (ACCRA). Separate from this study, but applying the exact same standards of calculation during the same time period, we conducted a cost-of-living study for Maryville, Bethany and Trenton, Missouri. Bethany's cost-of-living came in at 94.9 , while Trenton's was slightly higher, but still well below the national average, at 95.7 .

Incorporating these three city's data into the Missouri Average as calculated by ACCRA yielded a 1.1\% increase, making the cost-of-living for the state of Missouri 93.7. This resulted in a seventeenth place finish for Missouri when ranked against other state composite indices. Without our data included, the Missouri Department of Economic Development reported that during the $3^{\text {rd }}$ quarter, 2002 the state had the thirteenth-lowest cost-of-living in the United States.

Missouri Cost-of-living Study - $3^{\text {rd }}$ Quarter 2002

\begin{tabular}{|l|c|c|c|c|c|c|c|}
\hline & Grocery & Housing & Utilities & Transportation & Health Care & $\begin{array}{c}\text { Misc. } \\
\text { Composite } \\
\text { Index }\end{array}$ \\
\hline National Average & & & & & & & 100 \\
\hline Kansas City & 102.7 & 104.0 & 97.7 & 96.8 & 83.6 & 105.9 & 102.2 \\
\hline St. Louis & 108.0 & 93.8 & 107.2 & 103.0 & 97.6 & 101.2 & 100.7 \\
\hline Columbia & 95.8 & 93.1 & 95.6 & 101.1 & 93.3 & 100.0 & 96.8 \\
\hline Trenton & 87.3 & 108.9 & 103.2 & 78.6 & 69.2 & 95.8 & 95.7 \\
\hline Bethany & 87.4 & 93.9 & 88.2 & 88.5 & 110.3 & 102.9 & 94.9 \\
\hline Adj. Missouri Average & 92.9 & 91.2 & 92.7 & 92.9 & 89.0 & 97.6 & 93.7 \\
\hline Jefferson City & 96.4 & 81.3 & 101.1 & 97.2 & 83.5 & 98.8 & 92.8 \\
\hline Maryville & 83.7 & 95.1 & 87.2 & 93.3 & 83.1 & 90.3 & 90.3 \\
\hline St. Joseph & 85.2 & 80.4 & 83.8 & 96.2 & 89.2 & 96.2 & 88.7 \\
\hline Springfield & 95.5 & 78.7 & 77.7 & 93.3 & 97.1 & 93.6 & 88.6 \\
\hline Nevada & 87.3 & 82.7 & 85.1 & 80.6 & 83.5 & 91.7 & 86.4 \\
\hline Joplin & 83.5 & 74.9 & 93.7 & 79.5 & 93.1 & 92.2 & 84.9 \\
\hline
\end{tabular}


The following details an explanation of the components of the cost-of-living index; the methodology we used; and the detailed results of our study.

\section{WHAT IS A COST-OF-LIVING INDEX?}

The United States Department of Labor's Bureau of Labor Statistics provides the following definition: “a cost-of-living index measures differences in the price of goods and services, and allows for substitutions to other items as prices change" (http://www.bls.gov/bls/glossary.htm\#C). The overall process works as follows. Price measurements are gathered for a specific basket of goods and services, and each item is weighted to emphasize the individual importance of the item in relationship to the basket as a whole. The total cost of the market basket in a particular area is then compared to the national average cost of the market basket to determine an area's index value for a particular calendar quarter. These index values, gathered under the same strict methodological standards, can then be compared to other calculated index values from other geographic areas. Simply put, the major advantage of this procedure is such indices provide an "apples-to-apples" comparison for users of the data.

The selection of the items in the market basket and their corresponding weights are representative of typical consumer purchases. The ACCRA index method utilizes a market basket of goods typical of a family of four enjoying a "middle management" lifestyle. The traditional use of the cost-of-living index has been to compare the cost of an identical market basket of goods and services across various geographic locations, and to contrast the costs of living in specific areas. The Missouri Department of Economic Development study, and our study, both are calculated in accordance with the exact criterion and methodology used by the American Chamber of Commerce Research Association (ACCRA).

\section{ACCRA METHODOLOGY}

The cost-of-living index rules of construction, provided by the ACCRA, served as our template for this study. ACCRA's first cost-of-living index was published in 1968. They now support and publish indices for over 324 cities across the United States. The reliability and national acknowledgment of ACCRA standards qualifies the use of their methods for such a study, in our view.

These standards do allow for slight modifications when the area under study is particularly small, as Maryville, Bethany and Trenton are. The standards require a minimum of three price samples be taken for each item in the market basket of goods; however, in some instances, a particular good or service may not be available in three separate locations. For example, Maryville only has one bowling alley; one McDonald's; one Pizza Hut; one Kentucky Fried Chicken; one movie theater; one location which sells the Monopoly board game; and one location that sells tennis balls. The ACCRA methodology does allow one or two samples when that is all that is available, which makes perfect sense as the sample thus becomes equal to the population.

The market of basket of goods and services is comprised of fifty-seven items total. The items are grouped within the following six major categories: Housing, Grocery, Health Care, Transportation, Utilities and Miscellaneous. These categories are weighted according to their overall significance among middle management household purchases. These weights are calculated using data from the Bureau of Labor Statistics and are provided to researchers by ACCRA. An itemized list of the goods and services priced in this study, and their corresponding individual weights and general descriptions can be found in Appendix A.

To be formally eligible for participation in the ACCRA study, a community must contain at least 30,000 people. Researchers in areas with smaller populations are encouraged and supported by ACCRA to replicate their method on our own, allowing us to produce results for Maryville, Bethany and Trenton, which all fell below the population threshold for participation.

One of the benefits of a cost-of-living study is the fact that it allows end users the opportunity to evaluate potential expenditure changes from relocation. For example, if City A has a composite cost-of-living index value of 
98.3, and City B has an index of 128.5, how much of an increase in after-tax income would be necessary for a family to maintain its present lifestyle when moving from City A to City B?

$100 *[($ City B - City A) $/$ City A $]=100 *[(128.5-98.3) / 98.3]=31 \%$

Similarly, the cost-of-living in moving from City B to City A would be less.

$100 *[($ City A - City B $) /$ City B $]=100 *[(98.3-128.5) / 128.5]=-24 \%$

Other benefits to end users include a comparable determination of wage rates for different job classifications; identification of relatively high and low cost areas; and the ability to evaluate a complete community in cost comparison to similar communities.

All data were collected during the first weekend of October, 2002. For the grocery item index (including a few miscellaneous goods) pricing was completed by personal visits to Maryville stores, using the ACCRA data collections worksheet as a guide. The gasoline component of the transportation index was also priced on a personal visit, while the tire-balancing and commuter fares components were priced over the telephone. The doctor, dentist and hospital visits were also priced over the phone. And finally, the polysporin ointment was priced along with the grocery items.

For the housing index values, we contacted various apartment complexes, realtors and builders by mail to gather the required information. Mortgage interest rates were obtained from three local banks to aid in calculation of home purchase payments. Subsequently, because the utilities index is directly tied to the housing specifications in the housing index, utility rate sheets were collected from local providers in accordance with the standard ACCRA method.

Finally, miscellaneous goods and services were priced using a variety of techniques. The following is a list of those items collected in personal visits: toothpaste; shampoo; dress shirt; slacks; hamburger; fried chicken; boy's underwear; tennis balls; movie; board game; liquor; beer; and wine. The data for the remaining items was collected over the telephone: dry cleaning; washing machine repair; newspaper subscription; pizza; barbershop haircut; woman's haircut; and bowling.

\section{CONCLUSION \& RESULTS}

The state of Missouri is a very affordable place to live! Maryville, Bethany and Trenton are Northwest Missouri communities with cost-of-living results consistent with the state average, and well below the national average.

A comparison between these three communities in our study showed the following. All three areas enjoyed below state average costs in grocery items and transportation. Utilities are less expensive in the Maryville and Bethany areas, while Trenton experiences extremely low healthcare costs. Housing is higher than the state average in all areas, and miscellaneous goods and services are more affordable in Maryville and Trenton.

As to why these larger differences exist, Maryville and Trenton are both home to higher education institutions, which may skew housing costs upward due to the increased demand on the housing stock for off-campus student accommodations. This particular argument/speculation gains strength when one considers Columbia, home of the flagship University of Missouri, had the highest housing cost of any city in Missouri. Bethany's interstate highway (I-35) location may have also influenced its relative cost of goods in some fashion.

Regardless of the source of the variation, we find the use of the ACCRA methodology to calculate cost-ofliving to be appropriate and manageable for most any community. Aside from assisting individuals and families in relocation calculations, this study also provides potential businesses and industries basic information needed when 
considering area location. It should also be useful to economic developers and community leaders in business attraction and retention.

With Special Assistance provided by Economic Development Officers Jeff Ellis, Bethany, MO and Rick Childers, Trenton, MO. And also with research assistance from undergraduate student Joshua Mason.

\section{REFERENCES}

1. Bureau of Labor Statistics, "BLS Handbook of Methods", U.S. Department of Labor Bulletin \#2490, April, 1997.

2. Bureau of Labor Statistics, US Department of Labor, "CPI Detailed Report", Data for January 2000.

3. Bureau of Labor Statistics, "The redesign of the CPI geographic sample", http://stats.bls.gov/mlr/ cpijw001.htm.

4. Bureau of Labor Statistics, New methodology for selecting CPI outlet samples, http://stats.bls.gov/mlr/ cpirc001.htm.

5. Bureau of Labor Statistics, Changing the item structure of the Consumer Price Index, http://stats.bls.gov/mlr/ cpiwl001.htm.

6. Garner, Elizabeth Hornbrook and Eckert, Jerry B., 1998 Cost of Living Indices for Colorado's Counties, working paper.

7. Missouri Department of Economic Development website http://www.ecodev.state.mo.us/mediastorage/ press/Dec00COL.html.

8. Moulton, Brent R., "Basic components of the CPI: estimation of price changes", Monthly Labor Review, December, 1993.

\section{Appendix A: Descriptions and Weights for 2002 Cost-of-living Index Goods and Services}

\begin{tabular}{|c|c|c|c|}
\hline Component & Item & Description & Weight \\
\hline Grocery & T-bone steak & Price per pound & .0365 \\
\hline & Ground beef/hamburger & Price per pound - lowest price & .0365 \\
\hline & Sausage & Price per pound - Jimmy Dean & .0475 \\
\hline & Frying Chicken & Price per pound - whole & .0474 \\
\hline & Chunk light tuna & 6-6.125 ounce can - Chicken of the Sea & .0353 \\
\hline & Whole milk & Half gallon carton & .0386 \\
\hline & Eggs & One dozen - Grade A, large & .0080 \\
\hline & Margarine & One pound - Parkay or Blue Bonnet & .0295 \\
\hline & Parmesan cheese, grated & 8 ounce canister - Kraft brand & .0295 \\
\hline & Potatoes & 10 pound sack - lowest price & .0217 \\
\hline & Bananas & Price per pound & .0441 \\
\hline & Iceberg lettuce & Head - about 1.25 pounds & .0217 \\
\hline & Bread, white & 24 ounce loaf, lowest price & .0913 \\
\hline & Cigarettes & Winston - king size & .0673 \\
\hline & Coffee, vacuum-packed & 13 ounce can - Folgers & .0689 \\
\hline & Sugar & 4 pounds - cane - lowest & .0333 \\
\hline & Corn flakes & 10 ounce - Post Toasties & .0458 \\
\hline & Sweet peas & 15-17 ounce can - Green Giant & .0058 \\
\hline & Tomatoes & 14.5 can - Hunt's & .0058 \\
\hline & Peaches & 20 ounce can - halves or slices - Del Monte & .0172 \\
\hline & Facial tissues & 175 count box - Kleenex brand & .0378 \\
\hline & Dishwashing powder & 50 ounce - Cascade brand & .0416 \\
\hline & Shortening & 3 pound can, all vegetable - Crisco brand & .0216 \\
\hline & Frozen orange juice & 12 ounce can - Minute Maid brand & .0519 \\
\hline & Frozen corn & 16 ounce, whole kernel - lowest price & .0115 \\
\hline & Baby food & 4-4.5 ounce jar, strained vegetables - lowest price & .0689 \\
\hline & Soft drink & 2 liter-Coca Cola & .0350 \\
\hline
\end{tabular}




\section{NOTES}

